\author{
Octafa Nuha \\ International Islamic \\ University of Malaysia \\ tafanuhazhaa@gmail.com
}

\section{Efektivitas UKM Al-Mujaddid dalam Meningkatkan Kemampuan Berbicara (Studi Deskriptif Kualitatif pada Mahasiswa UKM Jurusan Pendidikan Bahasa Arab Universitas Muhammadiyah Yogyakarta Tahun Ajaran 2018-2019}

DOI: $10.18196 / \mathrm{mht} .128$

\begin{abstract}
This study aims to explore how the process of Al-Mujaddid Arabic Language UKM activities and the extent of the effectiveness of these Arabic Language UKM activities in increasing the ability to speak Arabic to members of the PBA UMY Department of UKM.

The research used by the authors in compiling this thesis was field research using qualitative data analysis. The method used by the author in this study was an observation. In contrast, the observation technique used was a direct observation, where the author observed all subjects studied directly, and data collection methods were used in the form of documentation, oral tests, and guided interviews.

From the results, the process of Al-Mujaddid Arabic Language UKM activities in UMY in improving Arabic speaking ability PBA UMY students was effective, indicated by the results of oral tests on February 19, 2019. All students of the Arabic Language Department (PBA) of UMY, who were members of Al-Mujaddid, participated. Of all 23 students, most of them obtained good grades, with the following details, namely, 15 students reached above 65, and 8 students reached below 65.
\end{abstract}

Keywords: UKM Al-Mujaddid, Arabic, speaking skills, Effectiveness

\begin{abstract}
ABSTRAK
Penelitian ini bertujuan untuk mengetahui bagaimana proses kegiatan UKM Bahasa Arab Al Mujaddid dan sejauh mana efektivitas kegiatan UKM Bahasa Arab ini dalam peningkatan kemampuan berbicara bahasa Arab pada anggota UKM Jurusan PBA UMY.

Penelitian yang digunakan oleh penulis dalam menyusun skripsi ini adalah penelitian lapangan dengan menggunakan analisa data kualitatif. Adapun metode yang digunakan penulis dalam penelitian ini adalah observasi, teknik observasi yang digunakan adalah observasi langsung dimana penulis mengadakan pengamatan secara langsung terhadap segala subyek yang diteliti, dan metode pengumpulan data yang digunakan berupa dokumentasi, tes lisan, dan interview bebas terpimpin.

Dari hasil penelitian yang penulis lakukan bahwa proses kegiatan UKM Bahasa Arab A/-Mujaddid di UMY dalam peningkatan kemampuan berbicara bahasa Arab Mahasiswa PBA UMY dapat
\end{abstract}


dikatakan efektif, Hal tersebut ditunjukkan dengan hasil tes lisan yang telah dilaksanakan pada tanggal 19 Februari 2019 yang diikuti oleh semua mahasiswa PBA UMY yang merupakan anggota UKM Al-Mujaddid. Dari 23 mahasiswa sebagian besar mendapatkan nilai bagus, dengan rincian sebagai berikut, yaitu 15 mahasiswa mendapatkan nilai diatas 65 dan 8 santri mendapatkan nilai dibawah 65.

Kata kunci: UKM A/-Mujaddid, Bahasa Arab, keterampilan berbicara, Efektifitas

\section{PENDAHULUAN}

Pada dasarnya, bahasa memiliki fungsi-fungsi tertentu yang digunakan berdasarkan kebutuhan seseorang, yakni sebagai alat untuk mengekspresikan diri, sebagai alat untuk berkomunikasi, sebagai alat untuk mengadakan integrasi dan beradaptasi sosial dalam lingkungan atau situasi tertentu, dan sebagai alat untuk melakukan kontrol sosial. Bahasa dalam prespektif apapun selalu memberikan pengaruh yang signifikan dalam kehidupan manusia (pola pembentukan cara pandang ideal). Dengan bahasa, manusia mulai menyadari pentingnya membangun sebuah komunikasi interaktif untuk membangun sebuah peradaban manusia. Dengan bahasa pula manusia mampu mendeteksi setiap perubahan (alami) yang ada dalam diri manusia dan bangsa (Afifudin, 2010: 245-246).

Pada pembelajaran bahasa Arab, kemampuan berbahasa Arab ditunjukkan dengan adanya kemampuan berbicara sebelum menunjukkan kemampuan-kemampuan yang lain. Berbicara adalah aktifitas berbahasa kedua yang dilakukan manusia dalam kehidupan bahasa setelah mendengarkan, dalam pembelajaran bahasa Arab kemampuan berbicara lebih dikenal dengan maharah kalam. Maharah Kalam sebagai salah satu kemampuan di dalam berbahasa menduduki peranan penting dibandingkan dengan kemampuan yang lain bahwa hakikat berbahasa sesungguhnya adalah pengucapan bunyi sebagai simbol-simbol pengungkapan diri dalam melakukan komunikasi antar sesama manusia sebagai makhluk hidup sosial. Secara umum maharah kalam bertujuan agar para pelajar mampu berkomunikasi lisan secara baik dan wajar mengandung arti menyampaikan pesan kepada orang lain dalam cara yang secara sosial dapat diterima. Dan kenyataannya dalam kehidupan sehari-hari membuktikan bahwa penguasaan bahasa 
lisan lebih fungsional daripada keterampilan berbahasa lainnya (Nurgiyantoro, 2011 : 399-400).

Namun tentu saja untuk mencapai tahap kepandaian berkomunikasi diperlukan aktivitas-aktivitas latihan memadai yang mendukung pelajar untuk mengembangkan kemampuan maharah kalam tersebut. Oleh karena itu, kemampuan berbicara seharusnya mendapat perhatian yang cukup dalam pembelajaran berbahasa.

Pembelajaran bahasa Arab di Asia Tenggara umumnya dan Indonesia Khususnya sudah berlangsung berabad abad lamanya. Akan tetapi aspek tata bunyi sebagai dasar kemahiran menyimak dan berbicara masih kurang diperhatikan. Menurut Chotib, hal ini disebabkan oleh tujuan pembelajaran bahasa Arab hanya diarahkan untuk menguasai bahasa tulisan dalam rangka memahami bahasa kitab kitab berbahasa Arab saja. Disisi lain, kemudian hakekat pengajaran bahasa lebih banyak didasarkan pada metode gramatika-terjemah, yaitu suatu metode mengajar yang banyak menekankan kegiatan belajar pada penghafalan kaidah-kaidah tata Bahasa dan penerjemahan kata per kata. Padahal metode ini tidaklah efektif dengan kompetensi yang hendak dicapai dalam keterampilan yang sasarannya berupa ujaran yaitu berbicara diajarkan peserta didik mulai dari tingkat sekolah dasar hingga perguruan tinggi. Namun pada umumnya dalam situasi resmi dan minimnya informasi informasi mahasiswa masih mengalami kesulitan untuk menyampaikan gagasan, pikiran, dan pertanyaan dalam bentuk lisan terutama dalam konteks pembelajaran bahasa asing khususnya bahasa Arab. Masih banyak mahasiswa yang masih merasa malu dalam berekspresi ketika berbicara ataupun berdialog dalam berbahasa Arab (Sulastri, 2016: 22).

Pendidikan pada dasarnya bukan hanya menjadi tanggung jawaab sekolah, tetapi menjadi tanggung jawab keluarga dan masyarakat. Kegiatan pendidikan yang didasarkan pada penjatahan waktu bagi masing - masing mata pelajaran sebagaimana tercantum dalam kurikulum sekolah lebih kita kenal dengan sebutan kurikuler. Sedangkan kegiatan yang diselenggarakan di luar jam sekolah agar lebih memperkaya dan memperluas wawasan pengetahuan dan kemampuan yang telah dipelajari dari berbagai mata pelajaran dalam kurikulum kegiatan ini disebut dengan kegiatan ekstrakurikuler. 
Kegiatan ini ada pada setiap jenjang pendidikan dari sekolah dasar sampai universitas. Pada universitas sering kita dengar dengan sebutan Unit Kegiatan Mahasiswa yang dimanfaatkan oleh para mahasiswa untuk mengembangkan kepribadian, bakat, dan kemampuannya di berbagai bidang, mulai dari seni, olah raga, pengembangan kepribadian, dan kegiatan lain yang bertujuan positif untuk kemajuan dari mahasiswa .

Unit Kegiatan Mahasiswa Al-Mujaddid adalah UKM yang bergerak dalam bidang bahasa Arab yang merupakan wadah untuk mengembangkan skill bahasa Arab. Dengan harapan mahasiswa dapat menguasai kemampuan bahasa Arab sesuai bidangnya.

Pada mahasiswa pendidikan bahasa Arab beberapa dari mereka yaitu sebagai anggota UKM Al-Mujaddid, yang mana mereka aktif dalam kegiatan yang ada di dalamnya. Menurut saya, dengan beberapa kegiatan yang ada pada UKM ini dapat memberikan pelajaran lebih tentang bahasa Arab, dapat membentuk lingkungan berbahasa Arab dan dapat meningkatkan wawasan tentang bahasa Arab yang kemudian akan mendorong proses belajar dalam pendidikan bahasa Arab.

Dalam pembelajaran bahasa Arab di bangku perkuliahan, selain peran dosen dalam menyampaikan materi peran aktifitas yang dapat menunjang softskill juga dapat mempengaruhi keefektifitasan mahasiswa dalam kemampuan berbicara. Hal ini menunjukkan bahwasannya mahasiswa yang mengikuti kegiatan soft skill di luar bangku perkuliahan memiliki nilai lebih dalam segi pengalaman dan praktek yang dapat meningkatkan kemampuan berbicara, idealnya mereka lebih unggul dalam pengaplikasian di kelas karena terbiasa dengan lingkungan berbahasa Arab yang telah mereka ciptakan dalam UKM.

Namun yang jadi menarik dalam pembelajaran bahasa Arab di PBA UMY ini mereka memiliki beberapa perbedaan dalam mempelajari bahasa Arab, salah satunya dengan pembentukan lingkungan berbahasa Arab di luar kelas tadi, Maka dari itu kemungkinan ada sedikit keunggulan terhadap mahasiswa yang mengikuti UKM Al-Mujaddid yang kemudian mempengaruhi beberapa aspek dalam pembelajaran bahasa Arab di PBA UMY khususnya dalam pembelajaran maharah kalam. 
Meihat beberapa kegiatan dalam UKM A/-Mujaddid maka peneliti ingin mempelajari dan meneliti sejauhmana efektifitas UKM A/-Mujaddid dalam meningkatkan ketrampilan berbicara pada mahasiswa anggota UKM Al-Mujaddid yang merupakan mahasiswa Pendidikan Bahasa Arab UMY. Dimana mahasiswa yang mengkuti UKM tersebut diprogramkan untuk berlatih setiap minggunya, sehingga memiliki nilai lebih terhadap mahasiswa yang tidak mengikuti UKM tersebut. Bahkan beberapa kali sejumlah mahasiswa kerap dikirim untuk mewakilkan beberapa lomba. Sehingga dalam UKM ini tercipta lingkungan berbahasa yang rapi, bagus terkondusif dan efektif. Karena dalam interaksi sosial tersebut selalu terjadi saling mempengaruhi.

Oleh karena itu peneliti tertarik untuk mengangkat judul penelitian skripsi yaitu Efektifitas UKM Al-Mujaddid dalam meningkatkan ketrampilan berbicara bahasa Arab pada anggota UKM Jurusan PBA UMY. Harapanya dengan penelitian ini dapat mengetahui efektifitas UKM Al-Mujaddid dalam meningkatkan kemampuan berbicara pada mahasiswa UMY 2017 yang mana dapat dibuktikan dengan nilai akademis dalam pembelajaran di kelas yang berkaitan dengan kemampuan berbicara.

\section{METODE PENELITIAN}

Dalam menguji dan meneliti hasil dalam pencarian fakta, peneliti menggunakan metode sebagai berikut:

\section{Jenis Penelitian}

Jenis penelitian ini adalah field research, dimana peneliti mengambil data dilapangan. Data diperoleh dengan melihat kegiatan pembelajaran kalam di UKM A/Mujaddid. Adapun jenis penelitian ini adalah penelitian kualitatif. Yang dimaksud dengan penelitian kualitatif adalah penelitian yang bermaksud untuk memahami fenomena tentang apa yang dialami oleh subjek penelitian secara holistic dan dengan cara deskripsi dalam bentuk kata-kata dan bahasa, pada suatu konteks khusus yang alamiah dan dengan memanfaatkan berbagai metode ilmiah.

Penelitian ini secara spesifik lebih diarahkan pada desain penelitian kualitatif deskriptif. Penelitian kualitatif deskriptif kali ini berusaha untuk menuturkan pemecahan 
masalah yang ada sekarang berdasarkan data-data yang diperoleh melalui tes lisan. Kemudian penelitian ini memberi gambaran secara cermat mengenai individu atau kelompok tertentu, tentang keadaan dan gejala yang terjadi. Maka dalam penelitian ini, peneliti akan menggunakan desain penelitian kualitatif deskriptif untuk menjelaskan bagaimana efektifitas UKM A/-Mujaddid dalam meningkatkan kemampuan berbicara mahasiswa PBA yang merupakan anggota UKM Al-Mujaddid dan dibantu dengan datadata tes yang di lakukan penulis, sehingga terlihat jelas rata-rata nilai tes jika disesuaikan dengan pengukuran efektifitas melalui teori Suharsmi Arikunto diatas.

\section{Tempat dan Subyek Penelitian}

Penelitian ini akan dilaksanakan di UKM A/-Mujaddid Universitas Muhammadiyah Yogyakarta dan dilaksanakan pada waktu semester genap tahun ajaran 2018-2019 pada bulan Januari - Februari 2018 dengan subyek penelitian mahasiswa Pendidikan Bahasa Arab yang sebagai anggota UKM Al-Mujaddid.

\section{Sumber Data}

a. Mahasiswa PBA Anggota UKM Al-Mujaddid, guna mengetahui sejauh mana UKM Al-Mujaddid dapat meningkatkan ketrampilan kalam Bahasa Arab mahasiswa.

b. Dosen PBA UMY, guna mengetahui perbedaan mahasiswa yang merupakan anggota UKM Al-Mujaddid dalam kegiatan d kelas terutama dalam pelajaran maharah kalam.

c. Pengurus UKM Al-Mujaddid, guna mengetahui gambaran tentang pembelajaran di UKM A/-Mujaddid dan untuk memperoleh informasi tentang kemampuan berbicara Bahasa Arab anggota UKM Al-Mujaddid khususnya mahasiswa PBA yang sebagai anggota UKM.

d. Alumni anggota UKM A/-Mujaddid, guna mengetahui pengalaman dan hasil pembelajaran bahasa Arab di UKM Al-Mujaddid.

\section{Variabel Penelitian}


a. Variabel bebas (independent variable) yaitu Mahasiswa PBA Anggota UKM Al-Mujaddid.

b. Variabel terikat (dependent variable) yaitu kemampuan berbicara Bahasa Arab.

\section{Teknik Pengumpulan Data}

Teknik pengumpulan data adalah cara-cara atau metode dan alat-alat yang dilakukan oleh peneliti dalam mengumpulkan data penelitian.

Dalam pengumpulan data yang dibutuhkan dalam penelitian ini terdapat metode yang digunakan, yaitu:

Teknik pengumpulan data yang digunakan dalam penelitian ini adalah sebagai berikut:

\section{a. Observasi}

Observasi atau pengamatan adalah suatu tehnik atau cara pengumpulan data dengan jalan mengadakan pengamatan terhadap kegiatan yang sedang berlangsung (Nana Syaodih Sukmaadinata, 2005: 220)

Adapun jenis observasi yang digunakan penulis adalah observasi partisipasi, yaitu peneliti terlibat dengan kegiatan sehari hari orang yang sedang diamati atau digunakan sebagai sumber data penelitian. Sambil melakukan pengamatan, peneliti ikut melakukan apa yang dikerjakan oleh sumber data, dan ikut merasakan suka dukanya. Dengan observasi partisipan ini, maka data yang diperoleh akan lebih lengkap, tajam dan sampai mengetahui pada tingkat makna dari setiap perilaku yang nampak. (Sugiyono, 200: hlm 204)

Dalam observasi peneliti menggunakan instrumen berupa pedoman observasi yang berisi geografis dan kondisi lingkungan UKM, struktur organisasi UKM, pelaksanaan pembelajaran bahasa Arab, keadaan sarana prasarana, serta kondisi guru dan siswa. Peneliti juga membutuhkan pedoman observasi berupa garis besar ataupun poin-poin unum dari kegiatan pembelajaran yang akan diobservasi.

b. Wawancara 
Wawancara adalah salah satu teknik pengumpulan dan pencatatan data, informasi atau pendapat yang dilakukan melalui percakapan dan Tanya jawab, baik langsung maupun tidak langsung dengan sumber data.

Wawancara ditujukan kepada pengurus dan mahasiswa PBA UMY anggota UKM untuk memperoleh informasi tentang pelaksanaan kegiatan UKM dan keterampilan berbicara yang telah dilaksanakan dan juga melakukan wawancara kepada ketua UKM terkait gambaran umum UKM Al- Mujaddid.

Metode wawancara yang digunakan penulis dalam penelitian ini ialah wawancara semi-terstruktur. Ciri-ciri dari wawancara ini adalah pertanyaan terbuka atau bebas namun tetap memiliki batasan tema dan alur pembicaraan, kecepatan wawancara dapat diprediksi, fleksibel tetapi terkontrol, ada pedoman wawancara yang dijadikan patokan alur, urutan dan penggunaan kata, dan tujuan wawancara adalah untuk memahami suatu fenomena (Haris Hardiansyah, 2011: 121)

Metode yang peneliti gunakan ini untuk megumpulkan data tentang gambaran umum sekolah dan bagaimana efektifitas UKM Al-Mujaddid dalam meningkatkan ketrampilan berbicara bahasa Arab mahasiswa PBA UMY anggota UKM Al-Mujaddid.

\section{Dokumentasi}

Dokumentasi adalah cara mengumpulkan data melalui benda-benda tertulis seperti buku-buku, majalah, dokumen, peraturan-peraturan, notulen rapat dan catatan harian (Arikunto: 2002, hlm 206)

Metode ini penulis gunakan untuk mendapatkan data mengenai sejarah dan profil UKM Al-Mujaddid, struktur organisasi, visi misi UKM, pengurus, keadaan sarana dan prasarana serta hal-hal yang terkait dengan efktifitas UKM Al-Mujaddid dalam meningkatkan ketrampilan berbicara bahasa Arab sebagai pelengkap data skripsi, Dan diperlukan sejumlah instrumen pengumpulan data seperti lembar pengamatan, alat rekam, kamera digital/hp, pedoman wawancara, pedoman observasi, lembar angket, dan alat tulis.

\section{Instrumen Penelitian}


Dalam penelitian kualitatif, yang menjadi instrument atau alat penelitian adalah peneliti sendiri, namun karena fokus penelitiannya sudah jelas yaitu mengenai efektifitas UKM Al-Mujaddid dalam meningkatkan kemampuan berbicara pada anggota UKM jurusan PBA UMY, maka dari itu dikembangkan instrumen penelitian dengan menggunakan tes lisan yang dilakukan peneliti dengan langkah-langkan dan hasil sebagai berikut.

\section{Kriteria Penilaian}

Kriteria Penilaian Tes Lisan Anggota UKM A/-Mujaddid Jurusan PBA tahun ajaran 2018 2019

\begin{tabular}{|c|c|c|c|c|}
\hline No & Kriteria Penilaian & Keterangan & $\begin{array}{l}\text { Nilai } \\
\text { (Huruf) }\end{array}$ & $\begin{array}{c}\text { Nilai } \\
\text { (Angka) }\end{array}$ \\
\hline 1 & Kesesuaian Pengucapan & $\begin{array}{l}\text { Kesesuaian kalimat yang } \\
\text { diucapkan }\end{array}$ & A & $85-100$ \\
\hline \multirow[t]{2}{*}{2} & \multirow[t]{2}{*}{ Kefasihan dan kelancaran } & $\begin{array}{l}\text { Kejelasan pengucapan } \\
\text { makhorijul huruf }\end{array}$ & A- & $80-84,9$ \\
\hline & & $\begin{array}{l}\text { Kesesuaian intonasi dan } \\
\text { lahjah }\end{array}$ & $\mathrm{B}+$ & $75-79,9$ \\
\hline \multirow[t]{3}{*}{3} & \multirow[t]{3}{*}{ Qowaid } & $\begin{array}{l}\text { Kesesuaian penggunaan } \\
\text { dhomir Muannas dan } \\
\text { Mudzakkar }\end{array}$ & B & $70-74,9$ \\
\hline & & $\begin{array}{l}\text { Kesesuaian penggunaan fil } \\
\text { madid dan fiil mudhori' }\end{array}$ & B- & $65-69,9$ \\
\hline & & $\begin{array}{l}\text { Kesesuaian penggunaan } \\
\text { Jumlah Ismiyah dan Fi'liyah }\end{array}$ & $\mathrm{C}+$ & $60-64,9$ \\
\hline
\end{tabular}




\begin{tabular}{|l|l|l|l|l|}
\hline 4 & Keberanian berpendapat & $\begin{array}{l}\text { Berani dan lancar dalam } \\
\text { mengungkapkan pendapat }\end{array}$ & $55-59,9$ \\
\hline 5 & Mufrodat & $\begin{array}{l}\text { Kesesuaian penggunaan } \\
\text { mufrodat dalam kalimat }\end{array}$ & D & $30-54,9$ \\
\cline { 2 - 5 } & $\begin{array}{l}\text { Penguasaan banyaknya } \\
\text { mufrodat }\end{array}$ & $0-29,9$ \\
\hline
\end{tabular}

Jenis penelitian ini adalah field research, dimana peneliti mengambil data di lapangan. Data diperoleh dengan melihat kegiatan pembelajaran kalam di UKM A/Mujaddid. Adapun jenis penelitian ini adalah penelitian kualitatif deskriptif, yang berusaha untuk menuturkan pemecahan masalah yang ada sekarang brdasarkan data-data seperti menjelaskan bagaimana efektifitas UKM A/-Mujaddid dalam meningkatkan kemampuan berbicara mahasiswa PBA yang merupakan anggota UKM Al-Mujaddid, maka peneliti menambahkan tes sebagai alat untuk memperkuat dan mengukur efektifitas, kemudian hasil dari penelitian ini diungkapan secara deskriptif.

Penelitian ini akan dilaksanakan di UKM A/-Mujaddid Universitas Muhammadiyah Yogyakarta dan dilaksanakan pada waktu semester genap tahun ajaran 2018-2019 pada bulan Januari - Februari 2018 dengan subyek penelitian mahasiswa Pendidikan Bahasa Arab yang sebagai anggota UKM Al-Mujaddid.

Peneliti menggunakan menggunakan teknik pengumpulan data seperti: observasi, wawancara dan dokumentasi, dengan pedoman masing-masing. Untuk responden, peneliti juga melaksanakan tes secara lisan sebagai alat ukur efektifitas UKM agar mendapat hasil yang akurat.

\section{HASIL PENELITIAN DAN ANALISIS}

Sebagaimana telah dijelaskan di atas bahwa efektivitas suatu pendekatan dalam proses pembelajaran dapat diukur dari banyaknya jumlah peserta didik yang berhasil 
mencapai seluruh tujuan belajar dalam waktu yang telah ditentukan (Mudlofir, 1990: 145146)

Spesifikasi jumlah tersebut dinyatakan dalam rata - rata hasil test setiap individu, sedangkan besarnya hasil tergantung kepada standar kriteria keberhasilan yang sudah ditentukan oleh pengajar.

Berikut Dalam penilaian dunia pendidikan kriteria pengukuran keefektivitasan yaitu:

$80-100$ : Sangat Efektif

66-79 : Efektif

$56-65$ : Cukup Efektif

$40-55 \quad$ : Kurang Efektif

30-39 : Tidak Efektif (Arikunto, $1984: 2517$ )

Kegiatan di UKM Al-Mujaddid tentunya memberikan manfaat dan dampak yang positif terhadap kemampuan berbicara bahasa Arab anggota UKM yang merupakan jurusan PBA karena dengan adanya kegiatan - kegiatan yang mendukung di UKM tersebut mahasiswa akan memperoleh pembendaharaan kosakata, wawasan tentang teori dan tentunya lingkungan yang mempengaruhi, yang nantinya akan banyak membantu mahasiswa dalam berbicara bahasa Arab.

Oleh karena itu untuk menilai efektivitas kegiatan UKM Al-Mujaddid dalam meningkatan kemampuan berbicara bahasa Arab anggota UKM yang merupakan mahasiswa PBA UMY, maka langkah pertama yang dilakukan penulis yaitu dengan cara melihat hasil prestasi mahasiswa dalam nilai ujian Istima Wal kalam yang ada pada setiap semester 1 di prodi PBA UMY dan kemampuan berbicara bahasa Arab anggota UKM yang merupakan mahasiswa PBA UMY yang diuji dalam tes lisan.

Berikut adalah hasil prestasi nilai mahasiswa PBA Anggota UKM Al-Mujaddid pada pelajaran Istima Wal Kalam:

\begin{tabular}{|l|l|l|l|}
\hline No & Nama & Angkatan & Nilai \\
\hline 1 & Nadzifa Ifti Fauziah & 2016 & A \\
\hline 2 & Nidaul Hasanah & 2016 & A \\
\hline
\end{tabular}




\begin{tabular}{|c|c|c|c|}
\hline 3 & \begin{tabular}{|ll} 
Eza & Alhaniah \\
Amalina &
\end{tabular} & 2016 & A- \\
\hline 4 & $\begin{array}{l}\text { Raka Imby Ageng } \\
\text { Seno }\end{array}$ & 2017 & $A$ \\
\hline 5 & Nisa Nurul Asfiyah & 2017 & $A$ \\
\hline 6 & Mega Robi'atullaela & 2017 & $A$ \\
\hline 7 & Qori Ainin Fauziah & 2017 & $A B$ \\
\hline 8 & Harmiaton & 2017 & $A$ \\
\hline 9 & $\begin{array}{l}\text { Ainnike Zakiyyatul } \\
\text { Fitriani }\end{array}$ & 2017 & $A$ \\
\hline 10 & Churfatul Jannah & 2017 & $A$ \\
\hline 11 & Urfa Zuyyina Alfarisi & 2017 & $A$ \\
\hline 12 & Rizal Yusuf Hanifa & 2017 & A \\
\hline 13 & $\begin{array}{l}\text { Muhammad Taufiq } \\
\text { Hidayat }\end{array}$ & 2018 & A \\
\hline 14 & $\begin{array}{ll}\text { Ahmad } & \text { Bahrum } \\
\text { Matdoan } & \end{array}$ & 2018 & $A$ \\
\hline 15 & Indra Adisaputra & 2018 & A \\
\hline 16 & $\begin{array}{l}\text { Austaqani } \\
\text { Filubudiyati }\end{array}$ & 2018 & $A B$ \\
\hline 17 & Eza Qurnia Hayati & 2018 & $B$ \\
\hline 18 & $\begin{array}{ll}\text { Rima } & \text { Rahmatul } \\
\text { Umimah } & \end{array}$ & 2018 & $A$ \\
\hline 19 & Gia Mupi Mu'ainun & 2018 & $\mathrm{~A}$ \\
\hline 20 & Novita Herlina & 2018 & $A B$ \\
\hline 21 & Elya Mawarni & 2018 & $A$ \\
\hline 22 & Khitoh Fatonah & 2018 & A \\
\hline 23 & Nina Apni & 2018 & $B$ \\
\hline
\end{tabular}


Berikut adalah hasil nilai ujian tes lisan yang diadakan penulis sebagai perbandingan mahasiswa setelah mengikuti UKM Al-Mujaddid, yang dilaksanakan pada hari Selasa 19 Februari 2019.

\begin{tabular}{|c|c|c|c|c|c|c|c|}
\hline \multirow[t]{2}{*}{ No } & \multirow[t]{2}{*}{ Nama } & \multicolumn{5}{|c|}{ Kriteria Penilaian } & \multirow{2}{*}{$\begin{array}{l}\text { Nilai } \\
\text { Total }\end{array}$} \\
\hline & & 1 & 2 & 3 & 4 & 5 & \\
\hline 1 & Nadzifa Ifti Fauziah & 70 & 70 & 65 & 70 & 65 & 68 \\
\hline 2 & Nidaul Hasanah & 70 & 70 & 60 & 70 & 50 & 64 \\
\hline 3 & Eza Alhaniah Amalina & 60 & 50 & 45 & 50 & 45 & 50 \\
\hline 4 & Raka Imby Ageng Seno & 60 & 50 & 60 & 50 & 45 & 53 \\
\hline 5 & Nisa Nurul Asfiah & 75 & 70 & 65 & 70 & 70 & 70 \\
\hline 6 & Mega Robi'atullaela & 70 & 65 & 60 & 70 & 60 & 65 \\
\hline 7 & Qori Ainin Fauziah & 70 & 55 & 60 & 60 & 55 & 60 \\
\hline 8 & Harmiaton & 75 & 70 & 70 & 75 & 60 & 70 \\
\hline 9 & Ainnike Zakiyyatul Fitriani & 85 & 85 & 75 & 80 & 75 & 80 \\
\hline 10 & Churfatul Jannah & 80 & 70 & 80 & 75 & 75 & 76 \\
\hline 11 & Urfa Zuyina Alfarisi & 75 & 70 & 70 & 70 & 65 & 70 \\
\hline 12 & Rizal Yusuf Hanifa & 85 & 85 & 80 & 85 & 80 & 83 \\
\hline 13 & Muhammad Taufiq Hidayat & 75 & 75 & 70 & 75 & 75 & 74 \\
\hline 14 & Ahmad Bahrum Matdoan & 90 & 95 & 95 & 90 & 90 & 92 \\
\hline 15 & Indra Adisaputra & 80 & 70 & 80 & 75 & 75 & 76 \\
\hline 16 & Austaqani Fillubudiyati & 75 & 75 & 60 & 70 & 60 & 68 \\
\hline 17 & Eza Qurnia Hayati & 70 & 50 & 50 & 70 & 50 & 58 \\
\hline 18 & Rima Rahmatul Ummah & 80 & 80 & 80 & 80 & 80 & 80 \\
\hline 19 & Gia Mupi Mu'ainun & 70 & 75 & 60 & 70 & 65 & 68 \\
\hline 20 & Novia Herlina & 75 & 70 & 70 & 70 & 65 & 70 \\
\hline 21 & Elya Mawarni & 65 & 60 & 65 & 70 & 65 & 65 \\
\hline 22 & Khitoh Fatonah & 80 & 75 & 70 & 75 & 75 & 75 \\
\hline 23 & Nina Apni & 65 & 65 & 60 & 60 & 50 & 60 \\
\hline
\end{tabular}


Sebagaimana disebutkan pada bab kedua, bahwa suatu kegiatan dapat dikatakan sangat efektif dalam suatu pembelajaran adalah apabila para mahasiswa dapat menguasai materi dan disamping itu adanya pencapaian yang sesuai. Berdasarkan dari data nilai hasil tes lisan diatas, yang telah dilaksanakan pada tanggal 19 Februari 2019, dan diikuti oleh semua anggota UKM yang merupakan mahasiswa PBA UMY, dapat disimpulkan bahwa kegiatan - kegiatan UKM Al- Mujaddid efektif, karena sebagian besar dari mereka mendapatkan nilai di atas 65 maka dikatakan efektif.

Dari dafar nilai diatas dapat diketahui bahwa dari 23 mahasiswa yang mendapatkan nilai diatas 65 berjumlah 15 mahasiswa, sebagaimana table dibawah ini:

DAFTAR MAHASISWA YANG MENDAPATKAN NILAI DIATAS 65

\begin{tabular}{|l|l|l|l|}
\hline No & Nama & Angkatan & Nilai \\
\hline 1 & Nadzifa Ifti Fauziah & 2016 & 68 \\
\hline 2 & Nisa Nurul Asfiah & 2017 & 70 \\
\hline 3 & Harmiaton & 2017 & 70 \\
\hline 4 & Ainnike Zakiyyatul Fitriani & 2017 & 80 \\
\hline 5 & Churfatul Jannah & 2017 & 76 \\
\hline 6 & Urfa Zuyina Alfarisi & 2018 & 70 \\
\hline 7 & Rizal Yusuf Hanifa & 2018 & 83 \\
\hline 8 & Muhammad Taufiq Hidayat & 2018 & 74 \\
\hline 9 & Ahmad Bahrum Matdoan & 2018 & 92 \\
\hline 10 & Indra Adisaputra & 2018 & 76 \\
\hline 11 & Rima Rahmatul Ummah & 2018 & 80 \\
\hline 12 & Gia Mupi Mu'ainun & 2018 & 68 \\
\hline 13 & Novia Herlina & 2018 & 70 \\
\hline 14 & Khitoh Fatonah & 2018 & 75 \\
\hline 15 & Austaqani Fillubudiyati & 2018 & 68 \\
\hline
\end{tabular}


Sedangkan mahasiswa yang mendapat nilai dibawah 65 sebanyak 8 mahasiswa, sebagaimana dalam daftar tabel dibawah ini:

DAFTAR MAHASISWA YANG MENDAPATKAN NILAI DIBAWAH 65

\begin{tabular}{|l|l|l|l|}
\hline No & Nama & Angkatan & Nilai \\
\hline 1 & Nidaul Hasanah & 2016 & 64 \\
\hline 2 & Eza Alhaniah Amalina & 2016 & 50 \\
\hline 3 & Raka Imby Ageng Seno & 2017 & 53 \\
\hline 4 & Mega Robi'atullaela & 2017 & 65 \\
\hline 5 & Qori Ainin Fauziah & 2017 & 60 \\
\hline 6 & Eza Qurnia Hayati & 2018 & 58 \\
\hline 7 & Elya Mawarni & 2018 & 65 \\
\hline 8 & Nina Apni & 2018 & 60 \\
\hline
\end{tabular}

Dari data-data diatas, maka dapat disimpulkan bahwa kegiatan - kegiatan pada UKM Al- Mujaddid UMY dapat dikategorikan EFEKTIF.

\section{KESIMPULAN}

Setelah menguraikan hasil penelitian, dari skripsi ini dapat diambil beberapa kesimpulan sebagai jawaban atas rumusan masalah tentang Efektifitas UKM Al-Mujaddid dalam meningkatkan kemampuan berbicara pada Anggota UKM jurusan PBA UMY tahun ajaran 2018-2019, maka penulis dapat mengambil kesimpulan seperti berikut :

Dari hasil penelitian yang telah penulis lakukan, bahwasannya pelaksanaan kegiatan UKM Al-Mujaddid, yang terdiri atas kelaas sore dan Seni Budaya ini dilakukan setiap harinya sesuai jadwal yang ditentukan dengan pengajar yang telah di pilih dari alumni maupun dari mahasiswa, ataupun pengurus. Materi yang di sampaikan 
berdasarkan kelas yang telah di bagi menjadi 2, yaitu kelas dasar dan kelas pengembangan, kelas dasar untuk anggota yang belum pernah sekali belajar berbahasa Arab materi mengenai dan kelas pengembangan bagi anggota yang pernah mempelajari bahasa Arab. Buku yang digunakan sebagai bahan ajar yaitu buku Durusulluhoh dari Darussalam Press Gontor. Adapun kegiatan Seni Budaya yang lebih memberi praktek untuk meningkatkan kemampuan berbicara adalah kegiatan seni budaya, yaitu kegiatan latihan seperti: debat bahasa Arab, pidato bahasa Arab, puisi bahasa Arab. Biasanya kegiatan ini di peruntukkan kepada anggota yang telah memilih masing-masing bidangnya. Kegiatan ini diampu oleh pengajar yang telah menguasai bidangnya, kemudian beberapa kali anggota dari kegiatan ini mengkuti lomba dalam kancah regional maupun internasional.

1. Kegiatan UKM A/-Mujaddid yang dapat meningkatkan kemampuan berbicara pada anggota UKM jurusan PBA UMY dapat tergolong efektif, yaitu dpat di tunjukkan dengan hasil tes lisan yang dilakukan oleh peneliti pada tanggal 19 Februari 2019 yang diikuti seluruh anggota UKM Al-Mujaddid yang merupakan mahasisiwa PBA UMY, sebagian besar dari mereka mendapatkan nilai di atas 65 yang tergolong efektif yaitu sebanyak 15 mahasiswa dari 23 mahasiswa.

2. Faktor pendukung dan faktor penghambat

Faktor pendukung dalam kegiatan di UKM Al- Mujaddid sebagai berikut:

a. Pengajar / Guru

b. Apresiasi

C. Siswa yang memiliki latar belakang Pondok pesantren

Faktor penghambat dalam kegiatan di UKM A/-Mujaddid sebagai berikut:

a. Kurang terorganisirnya RPP dan Silabus

b. Kurangnya sarana yang memadai

\section{SARAN-SARAN}

1. Kepada Pengurus UKM Al-Mujaddid

a. Lebih mengoptimalkan seluruh kegiatan yang ada di Al-Mujaddid 
b. Untuk bagian pengajaran perlu di perbaiki terkait penyusunan RPP dan silabus pengajaran, agar proses belajar mengajar berjalan dengan baik dan tersusun rapi.

c. Hendaknya pengurus meningkatkan sarana dan prasarana yang memadai

d. Hendaknya memberi kedisiplinan berbahasa guna meningkatkan kualitas berbahasa

e. Hendaknya membiasakan lingkungan berbahasa ketika kegiatan berlangsung

f. Hendaknya memberi motivasi kepada mahasiswa yang baru mempelajari Bahasa Arab

2. Kepada Anggota UKM jurusan PBA

a. Hendaknya memanfaatkan UKM A/-Mujaddid sebagai wadah atau tempat untuk mengembangkan kemampuan berbahasa Arab, kemampuan berbicara khususnya.

b. Hendaknya para mahsiswa menyadari akan manfaat dari kegiatan UKM A/Mujaddid sebagai kegiatan yang dapat menunjang kemahiran berbicara dan memahami bahasa Arab.

c. Lebih meningkatkan kedisiplinan dalam mengikuti kegiatan UKM A/-Mujaddid.

d. Hendaknya mahasiswa lebih serius dan disiplin dalam mengikuti kegiatan UKM A/-Mujaddid, dan sering-kali mempraktekkan bahasa Arab.

\section{REFERENSI}

Afifudin. Neuropsikolinguistik. Jakarta: PT Raja Grafindo Persada, 2010.

Arikunto, Suharsimi. Dasar-Dasar Evaluasi Pendidikan. Jakarta: Bina Aksara, 1984.

Arikunto, Suharsimi. Prosedur Penelitian: Suatu Pendekatan Praktek. Jakarta: Rineka Cipta, 2002.

Hardiansyah, Haris. Metode Penelitian Kualitatif. Jakarta: Salemba Humanika, 2011.

Hermawan, Acep. Metodologi Pembelajaran Bahasa Arab. Bandung: PT Remaja Rosydakarya Offset, 2009. 
Khakim, Indy G. Kamus Cerdas Pengetahuan Is/am. Blora: Pustaka Kaona, 2008.

Mudlofir. Teknologi Instruksional. Bandung: PT Remaja Rosdakarya, 1990.

Mulyana, E. Manajemen Berbasis Sekolah. Bandung: Remaja Rosdakarya, 2003.

Nurgiyantoro, Burhan. Penilaian dalam Pengajaran Bahasa dan Sastra. Yogyakarta: BPFE, 2011.

Sulastri. "Pengembangan Media Pembelajaran Arabic Thematic Video Pada Ketrampilan Berbicara Bagi Siswa Kelas VII MTS". Journal of Arabic Learning and Teaching, Vol. 5, No. 1, 2016.

Sugiyono. Metode Penelitian Kuantitatif dan Kualitatif dan R\&D. Bandung: Alfabeta, 2009.

Sujud, Aswarni. Matra Fungsional Pendidikan. Yogyakarta: Purba Sari, 1989.

Syaodih, Nana Sukmanadinata. Metode Penelitian Pendidikan. Bandung: Remaja Rosdakarya, 2005.

Zulhannan. Teknik Pembelajaran Bahasa Arab Interaktif. Jakarta: PT Raja Grafindo Persada, 2014. 